\title{
A study of sea surface temperature effect on purse seine catch in Aceh North Waters, Indonesia
}

\author{
Ratna Mutia Aprilla ${ }^{1}$, Junaidi M. Affan ${ }^{1}$, Rahmatul Fitri ${ }^{1}$, Rianjuanda Djamani ${ }^{1}$, Afdhal Fuadi ${ }^{2}$, and Imelda Agustina ${ }^{1 *}$ \\ ${ }^{1}$ Fisheries Resource Utilization Study Program, Marine and Fisheries Faculty, Syiah Kuala University, Darussalam, Banda Aceh, \\ 23111, Indonesia. \\ ${ }^{2}$ Program Studi Perikanan, Fakultas Kelautan dan Perikanan, Universitas Teuku Umar, Meulaboh, 23615, Indonesia.
}

\begin{abstract}
Aceh fishermen in Ocean Fishing Port Kutaraja Banda Aceh generally carry out fishing operations around Aceh North waters which have abundant and diverse biological potential. Catches in Aceh North waters are still heavily influenced by several natural factors that often occur in certain seasons, one of which is the factor of Sea Surface Temperature (SST) based on this research about the effect of SST on purse seine catches based in Kutaraja Banda Aceh Ocean Fishery Port. This study aims to determine the catches of purse seine fishermen in Kutaraja Ocean Fishery Port to know the SST distribution, and to determine the effect of SST on purse seine catches based in Kutaraja Banda Aceh Ocean Fishery Port. This research was conducted in November 2019 at Kutaraja Ocean Fishery Port. Data analysis used in this study is purse seine catch data obtained from UPTD from 2015-2019 tabulated in tabular and graphical format, SST distribution obtained from Aqua-MODIS satellites from 2015-2019 using SeaDas software and analysis used to see the effect of SST on catch is using linear regression analysis. The conclusian is based on the results of studies on how ocean SPL affect the fish catches using purse seine with the highest vessel size of $11-20$ GT in 2018 with a total of 2,499,634 kg while the lowest catch in 2016 with a total of $1,460,220 \mathrm{~kg}$. SST distribution found in Aceh North waters shows that the highest temperature occurred in 2015 which was $30.24^{\circ} \mathrm{C}$ while the lowest occurred in 2016 which was $29.04^{\circ} \mathrm{C}$. From linear regression analysis results showed that SST in Aceh North waters showed a coefficient of determination $\left(\mathrm{R}^{2}\right)$ of 0.2279 . This value can give a picture that the SST parameters contribute to fish catches of $22.79 \%$ and the rest is influenced by other oceanographic factors. While the correlation coefficient (r) of 0.477 means that this condition can indicate sufficient correlation have a positive
\end{abstract}

\section{Introduction}

Aceh Province is located between $01^{\circ} 58^{\prime} 37.2^{\prime \prime}-06^{\circ} 04^{\prime}$ 33.6" North Latitude and $94^{\circ} 57^{\prime} 57.6^{\prime \prime}-98^{\circ} 17^{\prime} 13.2^{\prime \prime}$ East Longitude with an average altitude of 125 meters above sea level. Aceh province boundaries from the north and east are bordered by the Malacca Strait. In the south with the province of North Sumatra and in the west with the Indonesian Ocean [1].

Acehnese fishermen in Ocean Fishery Port Kutaraja generally carry out fishing operations around the Aceh northern waters. There have abundant and diverse potential for biological resources. Therefore, the Aceh northern waters are used as fishing operations areas (Fishing ground). The water was often used for fishing and was a migration line, thus promoting the fishing economy of Aceh [2, 3].

Aceh northern waters have small islands such as Sabang Island, Breueh Island, Tunom Island, Nasi Island and Buntal Island. It has a geographical location of $05^{\circ} 00^{\prime} 00^{\prime \prime}-06^{\circ} 00^{\prime} 00^{\prime \prime}$ North Latitude and $95^{\circ} 00^{\prime} 00^{\prime \prime}$ $96^{\circ} 00^{\prime} 00^{\prime}$ East Longitude [2]. Oceanographic conditions and economic value of a fishing area are a consideration whether or not to carry out fishing activities in the fishing area. To consider a location in the sea suitable for fishing, several oceanographic parameters are usually considered, i.e the physical, chemical and biological characteristics of the location, including sea surface temperature [4]. The life patterns of a fish are in insparable with environmental conditions. Fluctuations in environmental conditions have had a profoud effeect on fish existence [5]. One such SPL has a biological influence on the metabolism on the fish, judging by its physical effects. Therefore, the purpose of the study is to see and connect the SST studies with catch.

\section{Materials and Methods}

\subsection{Research location and time}

This research was conducted at Kutaraja Ocean Fishery Port Banda Aceh in November 2019 with a geographical position located at 5.56"62'110 North Latitude and

\footnotetext{
*Corresponding author: agustinaimelda1208@yahoo.com
} 
95.33"55'210 East Longitude. The research location map is presented in Figure 1.

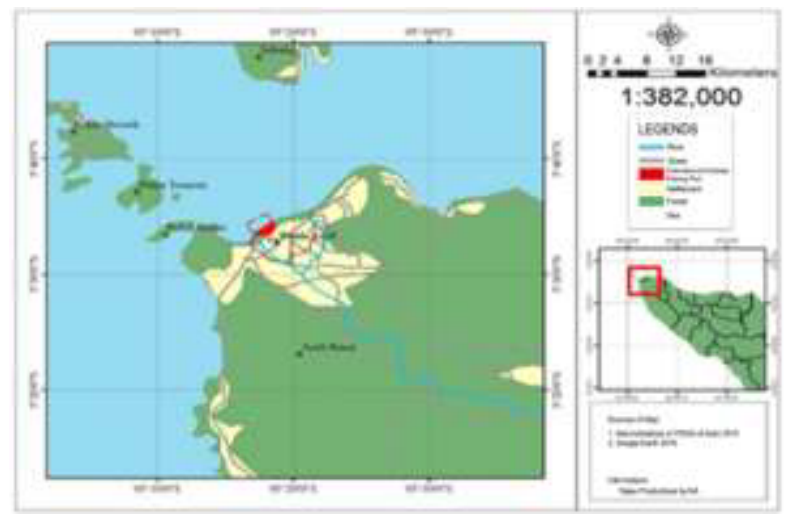

Fig. 1. Research sites

Tools and materials used in this study are: (1) Computer: Media processing data (2) Stationery: recording, (3) Microsoft office excel: Processing data, (4) Capture fisheries statistics book: Supplementary reference, (5) Aqua-MODIS: SST data collection, (6) SeaDas application Type 7.3: Processing SST data (7) Arc Gis Type 10.3: To create SST maps: and (8) Questionnaire: To obtain information from respondents.

Method used in this study is a survey method conducted by conducting interviews based on questionnaires to fishermen in purse seine 11-20 GT. Fishing fleet determination and fishermen as respondents was determined by the purposive sampling method (deliberately) namely purse seine measuring 11 to 20 Gross tonnage (GT) located at the Kutaraja Ocean Fishery Port.

\subsection{Data analysis}

Based on the purpose above, data analysis is divided into three stages.

\section{Fish Catch}

Collecting data on the number of catches obtained from the Kutaraja unit per month for the last five years, $2015,2016,2017,2018$, and 2019, next is to calculate the total catch of 11-20 GT purse seine that have been classified, tabulated, then reviewed in tabular and graphic formats.

2. Sea Surface Temperature Distribution

Data on sea surface temperatures distribution is known from A-qua-MODIS satellite imagery and processed with SeaDas software (Sea Data Analysis System), then processed again with Arc Gis 10.3 software for making fishing area maps. SST distribution image that has been processed is then issued a concentration value based on the fishing area.

3. SST Effect on Catches

To see SST effect on catch of purse seines, Regression Analyst Method was used with the following formula:

$$
\mathrm{Y}=\mathrm{a}+\mathrm{bx}
$$

Where:

$$
\mathrm{Y} \quad=\text { Fish catch }(\mathrm{kg})
$$$$
\text { a }=\text { Constant }
$$

$$
\begin{array}{ll}
\mathrm{b} & =\text { Regression coefficient } \\
\mathrm{x} & =\text { Sea surface temperature }(\mathrm{SST})
\end{array}
$$

\section{Results and Disscussion}

Catches number of 11-20 GT purse seine for the last 5 years (2015-2019) at the Kutaraja Ocean Fishery Port (PPS) was the highest in 2018 of 2,499,634 kg and the lowest in 2016 with a total of 1,464,220 kg (Figure 2).

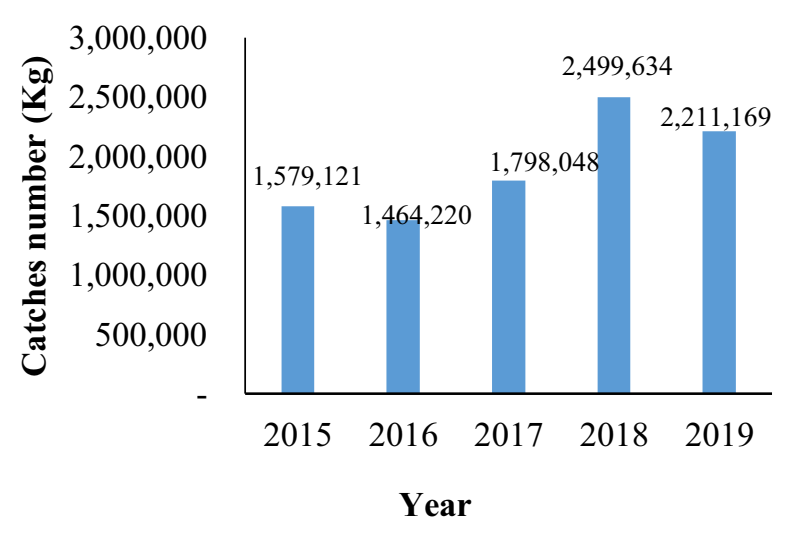

Fig. 2. 11-20 GT purse seine

SST content obtained in Aceh northern waters shows that the sea surface temperature in 2016 to 2019 started from the lowest temperature of $29.04{ }^{\circ} \mathrm{C}$ occurred in 2016 and reached the highest temperature of $30.24{ }^{\circ} \mathrm{C}$ occurred in 2015 with an average value of the average sea surface temperature of $29.86^{\circ} \mathrm{C}$ (Figure 3).

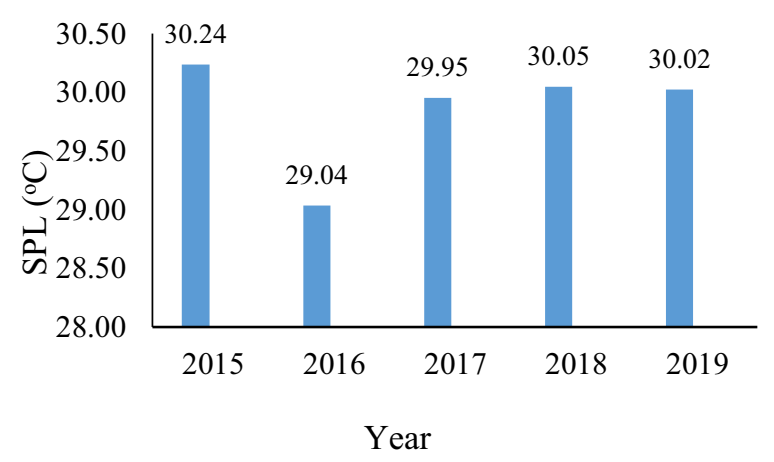

Fig. 3. Average distribution of sea surface temperature in the waters of North Aceh

Table 1. Average distribution of sea surface temperature in the waters of North Aceh

\begin{tabular}{|c|c|c|}
\hline No & Acquisition Time & Average SPL \\
\hline 1 & 2015 & 30.24 \\
\hline 2 & 2016 & 29.04 \\
\hline 3 & 2017 & 29.95 \\
\hline 4 & 2018 & 30.05 \\
\hline 5 & 2019 & 30.02 \\
\hline
\end{tabular}

Source: Satellite imagery (processed)

The average temporal distribution of sea surface temperatures in Aceh North waters is different every year, starting from the highest sea surface temperature to the lowest. It can provide an illustration that there is a dynamic change in dynamics of fishing areas in Aceh 
North waters (Table 1). The symptom factors that occur due to changes in condition of these oceanographic parameters are one of the parameters to be able to determine a potential and environmentally friendly fishing area.

Sea surface temperature can be used as an indicator to be able to determine the presence of a type of fish in a water, because each type of fish has a certain temperature tolerance that is preferred for its survival thus it affects their presence and distribution. Therefore, temperature is very important in determining a fishing area.

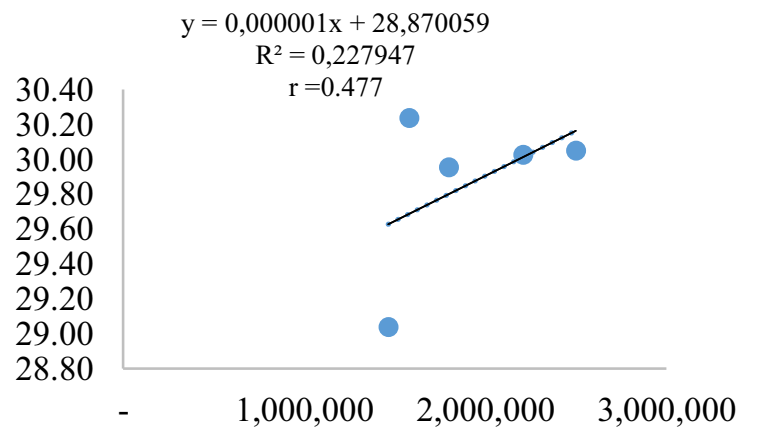

Fig. 4. Effect of sea surface temperature on fish catch

Based on Figure 4. show that the effect of fish catches graph on changes in sea surface temperature at Aceh North waters, the coefficient of determination (R2) is 0.2279 . This value can provide an illustration that the sea surface temperature (SST) parameter contributes to fish catches by $22.79 \%$ and the rest is influenced by other oceanographic factors and production factors. While the value of the correlation coefficient ( $r$ ) is 0.477 , meaning that this condition can indicate a sufficient correlation have a positive relationship.

The number of fish caught at Kutaraja Ocean Fishing Port (PPS) by purse seine vessel measuring 11 -20 GT for 5 years was the highest in 2018 which was $2,499,634$ $\mathrm{kg}$ and the lowest occurred in 2016 which was $1,464.220$ $\mathrm{kg}$ in Aceh north waters. Catch types for the last five years (2015-2019) were dominated by scad, tuna, also mackerel with each total catch of $8,331,785 \mathrm{~kg}$, $1,115,237 \mathrm{~kg}$ and $105,170 \mathrm{~kg}$. Either, the most dominant catches of small pelagic fish on land in Kutaraja Ocean Fishing Port are scad and tuna [2,6]. Changes to the SPLdue to the transition seasoneast - west in the waters of Aceh so that the results catch caused theso the fluctuations are not too much different.

Sea surface temperature that occurs in Indonesia in the East monsoon is lowly, while the sea surface temperature in West monsoon tends to be warmer when compared to temperature in the East monsoon [7]. According to [8], sea surface temperature in the West monsoon (December to February) is on average $4^{\circ} \mathrm{C}$ hotter than the East monsoon (June to August).

According to [9]), temperature is one of oceanographic parameters that expected to have a relationship with the life of fish or marine biota in particular and marine biological resources in general. Most marine biota like the optimum temperature or according to the body needs so that temperature is one of the most important factors in regulating life processes and organisms spread in the waters [10].

According [5, 11], states that changes in water temperature below the optimum temperature can cause a decrease in fish moving activity and also in feeding activities and can inhibit survival [12], said that temperature can affect the fish spread or marine biota in waters, because temperature plays a big role in regulating metabolic processes in the fish's body, which functions as a regulator of body movement activities, for example swimming speed and as a nerve stimulus. Information on the existence of fish is one of the kays to success in the development of catch fisheries [13].

\section{Conclusion}

The SST in today's waters is not fluctuating too significantly, thanks to a large surge of fashionable sensors resulting in a SPL range still available in a wide area (low resolution).

Based on the results of studies on how ocean SPL affect the fish catches using 11-20 GT purse seine gear was in 2018 with a total of 2,499,634 kg while the lowest catch was in 2016 with a total of $1,460,220 \mathrm{~kg}$. Sea surface temperatures distribution in Aceh north waters shows that the highest temperature occurred in 2015 which was $30.24^{\circ} \mathrm{C}$ while the lowest occurred in 2016 which was $29.04^{\circ} \mathrm{C}$ with an average value of $29.86^{\circ} \mathrm{C}$. So, from the simple linear regression analysis results about sea surface temperature effect on fish catch shows that there is a sufficient correlation with positive relationship direction and coefficient of determination value $\left(R^{2}\right)$ is 0.2279 which means that the effect is $22.79 \%$ and other is influenced by other oceanographic factors, viz. chlorophyll-a, salinity and current.

Acknowledgment. The author thanked the head and staff units and Syahbandar Kutaraja Ocean Fishing Port also respondents who have helped provide related information and data.

\section{References}

1. [BPS Aceh] Central Bureau of Statistics Aceh. Aceh statistics book in Aceh Province regional figures. Banda Aceh (2018)

2. Kurnia., S. Purnawan, T. Rizwan. Mapping of small pelagic fishing areas in northern waters of aceh. Unsyiah Marine and Fisheries Student Scientific Journal, 1, 185-194 (2016)

3. Neliyana. Comparative analysis of purse seine fishing at Lampulau Coastal Fishing Port (PPP) Banda Aceh. Thesis, Spostgraduate school, Bogor Agricultural Institute (IPB) (2014)

4. Hartoko., A. Spatial distribution of thunnus.sp, vertical and horizontal sub-surface multilayer temperature profiles of in-situ agro float data in indian ocean. Journal of Coastal Development. 14, 61-74 (2010)

5. Jufri A, Amran MA, Zainuddin. Caracteristic of the claw fishing grounds in the wastern season in the 
waters of Bone. IPTEKS PSP Journal, 1, 1-10 (2014).

6. Makwiyah, A., Chaliluddin, M., Aprilla. RM, Affan, JM, Muhammadar, AA, Rahmadani, H., Miswar, E., and Firdus, F. The effectiveness of using FADs as fishing grounds in Pusong Waters, Lhokseumawe City. Depik Journal. 7, 119-126 (2018)

7. Sukresno, B., Kasa IW. Dynamical analysis of Banda Sea concerning with el nino, Indonesian through flow and monsoon by using satellite data and numerical model. Echotrophic Journal. 3, 8791 (2008)

8. Sulaiman, A. Banda Sea Turbulence (Preliminary Study of ARLINDO Microstructure). Directorate of Natural Resources Invertarization Technology (TISDA) Agency for the Assessment and Application of Technology (BPPT). Jakarta (2008)

9. Nontji, A. Nusantara Sea. Jakarta: Sjambatan Publisher. 372 p (2005) 9

10. Nybakken, J. Marine Biology an Ecological Approach. Jakarta: PT. grammar. 459 pp (1992) 10

11. Laevastu T, Hayes ML. Fisheries Oceanography and Ecology. New York: Fishering News (1981)

12. Baskoro. MS, Revelation. RI, Effendi. A. Migration and Distribution of Fish. Bogor: Fisheries and Marine Sciences Faculty, Bogor Agricultural Institute. 152 pp (2004)

13. Aguslina SE, Tadjuddah M, Mustafa A. Across Sea Surface Temperatures and Tracking Claw Areas in Banda Seawater. Halu Oleo University, 2, 41-49 (2016) 